\title{
Impact of Global Climate Change on Regional Water Resources: A Case Study in the Huai River Basin
}

\author{
Ju Qin¹, Hao Zhen-chun¹, Ou Geng-xin², \\ Wang $\mathrm{Lu}^{3}$ and Zhu Chang-jun ${ }^{4}$ \\ ${ }^{1}$ State Key Laboratory of Hydrology-Water Resources and Hydraulic Engineering, \\ Hohai University, Nanjing, \\ ${ }^{2}$ School of Natural Resources, University of Nebraska-Lincoln, Lincoln, \\ ${ }^{3}$ Delft University of Technology, Delft, \\ ${ }^{4}$ College of Urban Construction, \\ Hebei University of Engineering, Handan, \\ ${ }^{1,4}$ China \\ ${ }^{2}$ USA \\ ${ }^{3}$ The Netherlands
}

\section{Introduction}

As one of the most important environmental issues, climate change has attracted great attention of various governmental agencies and scientists around the world in the last decade. The Intergovernmental Panel on Climate Change (IPCC), which was co-established by the United Nations Environment Program and the World Meteorological Organization, regularly assesses the global impact of climate change. Climate change, with the main feature of global warming, has become an indisputable fact. The earth's surface temperature increased by $0.74^{\circ} \mathrm{C}$ in the recent 100 years $(1906 \sim 2005)$. Temperature change of China over the recent 100 years is consistent with the global trends, with the average increase of $0.5 \sim 0.8^{\circ} \mathrm{C}$ (IPCC, 2007). Global warming will probably accelerate the global hydrological cycle, resulting in temporal and spatial changes of various meteorological and hydrological variables such as rainfall and evapotranspiration, which directly leads to frequent occurrence and constant increase of such extreme hydrological events as floods and droughts, thereby further affecting the regional ecology as well as the survival environment of the human being.

When hydrological models driven by climate scenarios are used to evaluate the impact of climate change on water resources, climate scenarios can be divided into two types. One is the hypothetical climate change scenario based on the climate change trend, which is mainly used to analyze the sensitivity of water resources to climate change. Nash and Gleick (1991) used the conceptual hydrological model to study the influence of climate change on the basin's annual runoff assuming temperature increased by $2^{\circ} \mathrm{C}$ and the 
precipitation increased or decreased by $10 \%$ to $20 \%$. The improved distributed Xin'anjiang hydrological model was used to analyze the sensitivity of Huai River Basin runoff to climate change by assuming various temperature and precipitation changes (Hao et al., 2006). The hydrological impact of fictitious climate scenarios changes were reported in different basins (e.g., Schwarz, 1977; Beyene et al., 2010; Young et al., 2009). The other is the climate prediction of global circulation models (GCMs). With the continual improvement of global and regional climate models, researchers have made great progress in studying the attribution and prediction of spatial and temporal changes in hydrological processes. GCMs have become one of the most effective tools in constructing future climate change scenarios. Ozkul (2009) used the predicted results of climate change scenarios released publicly by the Fourth Assessment of IPCC in the Gediz and Buyuk Menderes River Basins, combined with water balance model to predict a $20 \%$ reduction of surface water resources under future climate change before 2030, and the percentage will increase to $35 \%$ and $50 \%$ by the years of 2050 and 2100 , respectively. Nijssen et al. (2001) adopted the predicted scenario results of four climate models, coupled with the Variable Infiltration Capacity (VIC) model to predict the change of hydrological cycle change trends in nine large, continental river basins in 2025 and 2045. Other scholars have also conducted considerable research (Beyene et al., 2010; Minville et al., 2008; Ellis et al., 2008; Edwin, 2007; Christensen and Lettenmaier, 2007; Koutsoyiannis and Efstratiadis, 2007; Nemec and Schaake, 1982;).

Many scientists used the prediction results of GCMs to drive a hydrological model to evaluate the impact of climate change on water resources. The research, however, are mostly based on a single GCM output or a specified number of GCMs. Regional simulation ability of different models is quite different from each other (Zhou and Yu, 2006; Hao, et al., 2010). In addition, uncertainty is greater for a single GCM simulation. However, the differences between different GCMs can be considered when more than one GCM is selected. Moreover, prediction stability and reliability could be increased through the statistical estimations, Very few studies, however, offer sufficient reasons for selecting GCM. Therefore, studying principles and methods of selecting GCMs are extremely important in the coupling study of global climate models and hydrological models.

\section{The evaluation of IPCC AR4 climate model's simulation performance}

\subsection{Introduction of global climate models}

Climate scenarios simulation and prediction results of 24 GCMs were published by the fourth assessment of IPCC Data Distribution Centre (IPCC-DDC), including nine prediction results under different emission scenarios, three of which-high emission SRES A2 (Special Report on Emissions Scenarios A2), middle- emission SRES A1B and low-emission emissions SRES B1 - are identified as the major future climate change scenarios. More detailed information about the models can be found at http://wwwpcmdi.llnl.gov/ipcc/about-ipcc.Php. Basic information of the 22 global climate models provided by IPCC AR4, is listed in Table 1 (Both the BCC_CM1 of China and the CCCMA_CGCM3.1 T61 of Canada are not available respectively for non-reference period data and vague description of the data structure). 


\begin{tabular}{|c|c|c|c|c|c|}
\hline \multirow{2}{*}{ Model Research Center } & \multirow{2}{*}{ Model } & \multirow{2}{*}{ Abbreviations } & \multicolumn{2}{|c|}{ Grid resolution (o) } & \multirow{2}{*}{$\begin{array}{l}\text { Time } \\
\text { range }\end{array}$} \\
\hline & & & Latitude & longitude & \\
\hline $\begin{array}{l}\text { Bjerknes Center for Climate } \\
\text { Research, Norway }\end{array}$ & BCM2.0 & BCM2 & 2.8125 & 2.79 & $1850 \sim 2099$ \\
\hline $\begin{array}{l}\text { Canadian Center for Climate } \\
\text { Modelling and Analysis, Canada }\end{array}$ & $\begin{array}{l}\text { CGCM3 } \\
\text { (T47 } \\
\text { resolution) }\end{array}$ & CGMR & 3.75 & 3.71 & $1850 \sim 2300$ \\
\hline $\begin{array}{l}\text { Centre National de Recherches } \\
\text { Meteorologiques, France } \\
\text { Australia's Commonwealth }\end{array}$ & CM3 & $\mathrm{CNCM} 3$ & 2.8125 & 2.79 & $1860 \sim 2299$ \\
\hline $\begin{array}{l}\text { Australia's Commonwealth } \\
\text { Scientific and Industrial } \\
\text { Research Organisation, } \\
\text { Australia }\end{array}$ & Mk3.0 & CSMK3 & 1.875 & 1.8652 & $1871 \sim 2200$ \\
\hline $\begin{array}{l}\text { Max-Planck-Institut for } \\
\text { Meteorology, Germany }\end{array}$ & $\begin{array}{l}\text { ECHAM5- } \\
\text { OM }\end{array}$ & MPEH5 & 1.875 & 1.865 & $1960 \sim 2200$ \\
\hline $\begin{array}{l}\text { Meteorological Institute, } \\
\text { University of Bonn, Germany } \\
\text { Meteorological Research } \\
\text { Institute of KMA, Korea } \\
\text { Model and Data Groupe at MPI- } \\
\text { M, Germany }\end{array}$ & ECHO-G & ECHOG & 3.75 & 3.711 & $1860 \sim 2100$ \\
\hline $\begin{array}{l}\text { Institude of Atmospheric } \\
\text { Physics, China }\end{array}$ & $\begin{array}{l}\text { FGOALS- } \\
\text { g1.0 }\end{array}$ & FGOAL & 2.8125 & 2.79 & $1850 \sim 2199$ \\
\hline $\begin{array}{l}\text { Geophysical Fluid Dynamics } \\
\text { Laboratory (US) }\end{array}$ & CM2.0 & GFCM20 & 2.5 & 2 & $1861 \sim 2100$ \\
\hline $\begin{array}{l}\text { Geophysical Fluid Dynamics } \\
\text { Laboratory (US) }\end{array}$ & CM2.1 & GFCM21 & 2.5 & 2 & $1861 \sim 2300$ \\
\hline & $\mathrm{AOM}$ & GIAOM & 4 & 3 & $1850 \sim 2100$ \\
\hline Gode & E-H & GIEH & 5 & 4 & $1880 \sim 2099$ \\
\hline & E-R & GIER & 5 & 4 & $1880 \sim 2300$ \\
\hline $\begin{array}{l}\text { Institute for Numerical } \\
\text { Mathematics, Russia }\end{array}$ & CM3.0 & INCM3 & 5 & 4 & $1871 \sim 2200$ \\
\hline $\begin{array}{l}\text { Institut Pierre Simon Laplace, } \\
\text { France }\end{array}$ & $\mathrm{CM} 4$ & IPCM4 & 3.75 & 2.535 & $1860 \sim 2230$ \\
\hline nstitute for & $\begin{array}{l}\text { MIROC3.2 } \\
\text { hires }\end{array}$ & MIHR & 1.125 & 1.1214 & $1900 \sim 2100$ \\
\hline Environmental Studies, Japan & $\begin{array}{l}\text { MIROC3.2 } \\
\text { medres }\end{array}$ & MIMR & 2.8125 & 2.79 & $1850 \sim 2300$ \\
\hline $\begin{array}{l}\text { Meteorological Research } \\
\text { Institute, Japan }\end{array}$ & CGCM2.3.2 & MRCGCM & 2.8125 & 2.79 & $1851 \sim 2300$ \\
\hline National Centre for & PCM & NCPCM & 2.8125 & 2.79 & $1870 \sim 2099$ \\
\hline Atmospheric Research, USA & CCSM3 & NCCCSM & 1.40625 & 1.400763 & $1890 \sim 2099$ \\
\hline $\mathrm{U}$ & HadCM3 & HADCM3 & 3.75 & 2.5 & $1860 \sim 2199$ \\
\hline$U$ & HadGEM1 & HADGEM & 1.875 & 1.25 & $1860 \sim 2100$ \\
\hline $\begin{array}{l}\text { National Institute of Geophysics } \\
\text { and Volcanology, Italy }\end{array}$ & SXG 2005 & INGSXG & 1.125 & 1.1215 & $1870 \sim 2100$ \\
\hline
\end{tabular}

Table 1. Information of 22 climate models of IPCC AR4. 


\subsection{Study area and data}

\subsubsection{Study area}

Located in eastern China, the Huai River originates in Tongbai mountain, south Henan Province, flowing through Henan and Anhui Provinces from west to east, and finally entering the Hongze Lake of Jiangsu Province. The Huai River Basin is between the Yangtze River and Yellow River Basins, stretching from $111^{\circ} 55^{\prime} \mathrm{E}$ to $121^{\circ} 25^{\prime} \mathrm{E}$ and from $30^{\circ} 55^{\prime} \mathrm{N}$ to $36^{\circ} 36^{\prime} \mathrm{N}$. The basin is in a north to south climatic transition zone, thus having a temperate monsoon climate with hot and rainy summer, as well as cold and dry winter. Rainfall is of uneven distribution during the year. About $60 \%$ of the annual precipitation concentrates between June and August. From mid-June to early July, the basin turns into rainy season, with a large amount of rainfall across a wide range, easily causing severe basin-wide floods. In wet years, the total precipitation is $300-500 \%$ of dry years. According to historical data, there were 42 floods in this basin in the 48 years from 1901 to 1948. In addition, the Huai River Basin is also the main water supply area and the main channel for the eastern route of South-to-North water diversion project. The hope of the project is to divert water over hundreds of kilometers from China's Yangtze River to the North China Plain (Berkoff, 2003).

Climate change of this area will affect scheduling and allocation of the entire east route project. In this paper, the area more than $120,000 \mathrm{~km}^{2}$ above Bengbu station is selected as the study area. The western part and southwest part of the area are mountains and hilly area, and the rest is plain. River and weather stations in the study area are as shown in Fig. 1.

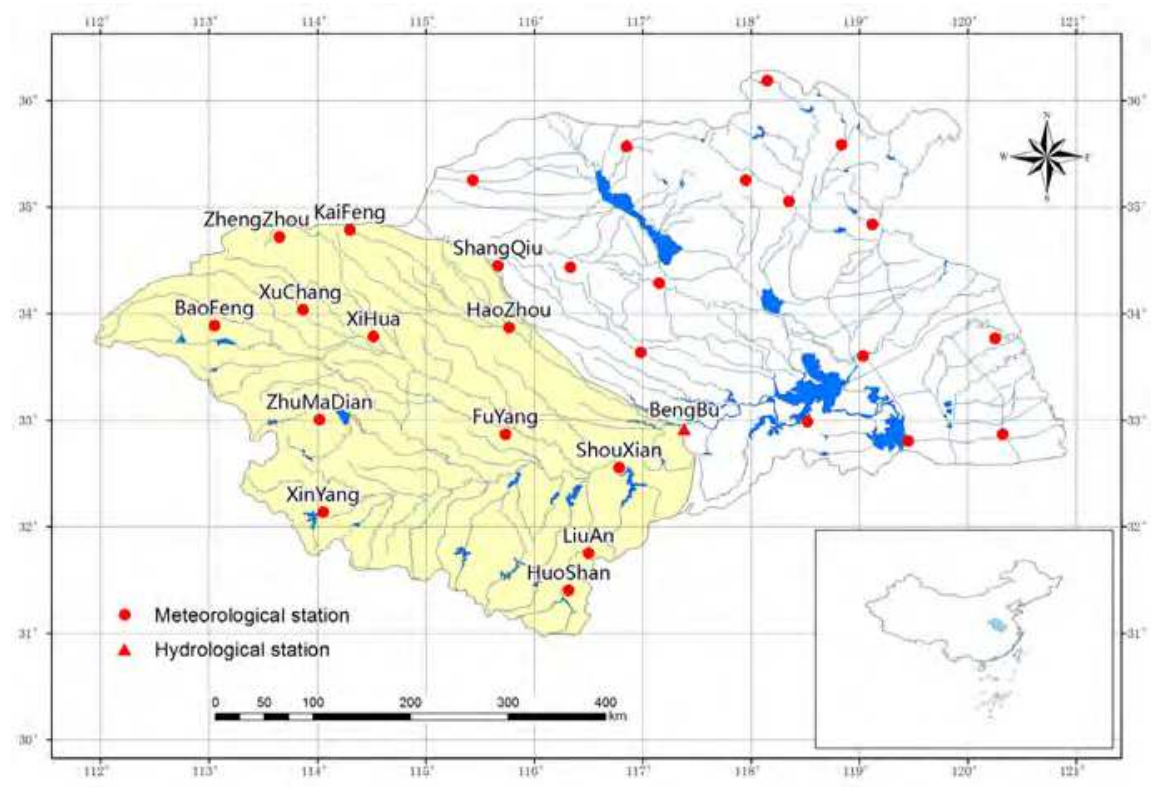

Fig. 1. The flow network and locations of the meteorological and hydrological stations in the Huai River Basin. 


\subsubsection{Data selection}

Information used in this study includes daily precipitation, temperature, and evaporation data for the period between 1951 and 2007 at 13 meteorological stations above the Bengbu station offered by the Climate Data Office of the China National Meteorological Information Center, as well as the monthly streamflow between 1915 and 2007 at the Bengbu hydrological station. Twenty-two global climate models, provided by the Fourth Assessment Report (IPCC AR4) of the Intergovernmental Panel on Climate Change (IPCC), are used to generate monthly average temperature and precipitation data in the contemporary climate $(20 \mathrm{C} 3 \mathrm{M})$ conditions of the reference period $(1961 \sim 1990)$, as well as future monthly temperature and precipitation data from 2001 to 2099.

\subsection{Evaluation of simulation performance of IPCC AR4 model}

In order to test the simulation capability of each model on temperature and precipitation in the Huai River Basin, we analyzed differences between simulated and observed values from different spatial and temporal scales. The simulated values are achieved from the original grid monthly temperature and precipitation provided by the models. Each single model's monthly regional average value in the reference period is also calculated by the geometric average. Relative error, absolute error, correlation coefficient and determination coefficient are used as indexes for performance evaluation (Ju, 2009).

Relative error, the formula is as follows

$$
\operatorname{MRE}=\sum_{i=1}^{n}\left[\left(P_{i}-O_{i}\right) / O_{i}\right] / n
$$

Where, $n$ is total calculation periods/intervals; $P_{i}$ is measured value of the ith period/interval.

Correlation coefficient, is used to evaluate the degree of fit of the measured value and the simulated values. The closer the value is to 1 , the more accurate the model is. The calculation formula is,

$$
R=\frac{\sum_{i=1}^{n}\left(O_{i}-\bar{O}\right)\left(P_{i}-\bar{P}\right)}{\left[\sum_{i=1}^{n}\left(O_{i}-\bar{O}\right)^{2}\right]^{0.5}\left[\sum_{i=1}^{n}\left(P_{i}-\bar{P}\right)^{2}\right]^{0.5}}
$$

Where, $\bar{O}$ is the average of the observed values; $\bar{P}$ is average of the calculated values.

Determination coefficient, also called Nash efficiency coefficient (Nash and Sutcliffe, 1970), can be used as an index to evaluate the degree of fit between the calculation process and the measurement process. The closer the value is to 1 , the more accurate the model is. The calculation formula is as follows:

$$
E=1.0-\frac{\sum_{i=1}^{n}\left(O_{i}-P_{i}\right)^{2}}{\sum_{i=1}^{n}\left(O_{i}-\bar{O}\right)^{2}}
$$




\subsubsection{Temperature}

From the comparison (Table 2) between the simulated results of climate models in the reference period $(1961 \sim 1990)$ and the observed data of regional average monthly temperature for the 13 weather stations in the Huai River Basin, it can be seen that correlation coefficients of all the models are very high, averaging above 0.97 , indicating that the models are capable of simulating temperature in the Huai River Basin. The annual average temperature of Huai River Basin in the reference period is $14.2^{\circ} \mathrm{C}$. The models perform differently in simulating temperature of these years. The simulated temperatures of all models are underestimated. We differentiated the models into two groups of larger deviation and smaller deviation, among which the simulated value of monthly average temperature (June to August) is consistent with the observation (Fig. 2). The IPCM4 model has the largest absolute error, which is $24.9^{\circ} \mathrm{C}$ lower than the observed temperature; $\mathrm{BCM} 2$ model has the smallest deviation of $0.2^{\circ} \mathrm{C}$. As to the evaluation index of determination coefficient, the value is expected to be close to 1.0 for a good simulation of the observed temperature. There are 11 models with the determination coefficient higher than 0 . Fig. 3 shows the difference between the average simulated temperature of CNCM3, CSMK3, HADGEM and NCCCSM and the observed values in the reference period.

\begin{tabular}{|c|c|c|c|c|c|c|c|c|c|}
\hline \multirow[b]{2}{*}{ Number } & \multirow[b]{2}{*}{ Model } & \multicolumn{2}{|c|}{ Analogue value } & \multirow{2}{*}{$\begin{array}{c}\text { Absolute } \\
\text { error of } \\
\text { tempe- } \\
\text { rature } /{ }^{\circ} \mathrm{C}\end{array}$} & \multirow{2}{*}{$\begin{array}{c}\text { Relative } \\
\text { error of } \\
\text { precipi- } \\
\text { tation/\% }\end{array}$} & \multicolumn{2}{|c|}{$\begin{array}{l}\text { Correlation } \\
\text { coefficient }\end{array}$} & \multicolumn{2}{|c|}{$\begin{array}{l}\text { Coefficient of } \\
\text { determination }\end{array}$} \\
\hline & & $\begin{array}{l}\text { Tempe- } \\
\text { rature } \\
/{ }^{\circ} \mathrm{C}\end{array}$ & $\begin{array}{c}\text { Precipi- } \\
\text { tation } \\
/ \mathrm{mm}\end{array}$ & & & $\begin{array}{l}\text { Tempe- } \\
\text { rature }\end{array}$ & $\begin{array}{c}\text { Precipi- } \\
\text { tation }\end{array}$ & $\begin{array}{l}\text { Temper- } \\
\text { ature }\end{array}$ & $\begin{array}{c}\text { Precipi- } \\
\text { tation }\end{array}$ \\
\hline$\overline{1}$ & BCM2 & 14.0 & 883.9 & -0.2 & 1.25 & 0.977 & 0.459 & 0.952 & 0.092 \\
\hline 2 & CGMR & 10.2 & 1251.0 & -4.1 & 43.30 & 0.981 & 0.323 & 0.755 & -0.536 \\
\hline 3 & $\mathrm{CNCM} 3$ & 13.8 & 850.7 & -0.5 & -2.55 & 0.978 & 0.486 & 0.943 & 0.134 \\
\hline 4 & CSMK3 & 12.2 & 714.5 & -2.1 & -18.16 & 0.982 & 0.59 & 0.912 & 0.262 \\
\hline 5 & ECHOG & -7.9 & 441.5 & -22.1 & -49.43 & 0.983 & 0.696 & -4.804 & 0.097 \\
\hline 6 & FGOALS & -4.4 & 672.6 & -18.7 & -22.96 & 0.979 & 0.728 & -3.456 & 0.442 \\
\hline 7 & GFCM20 & 9.6 & 963.7 & -4.7 & 10.39 & 0.973 & 0.438 & 0.691 & 0.017 \\
\hline 8 & GFCM21 & 11.0 & 886.0 & -3.2 & 1.49 & 0.974 & 0.439 & 0.831 & -0.01 \\
\hline 9 & GIAOM & -7.1 & 726.2 & -21.4 & -16.81 & 0.976 & 0.756 & -4.423 & 0.524 \\
\hline 10 & GIEH & -6.0 & 338.6 & -20.2 & -61.22 & 0.978 & 0.557 & -4.231 & -0.201 \\
\hline 11 & GIER & -6.3 & 298.4 & -20.6 & -65.82 & 0.971 & 0.44 & -4.412 & -0.354 \\
\hline 12 & HADCM3 & 12.9 & 997.4 & -1.3 & 14.25 & 0.981 & 0.524 & 0.944 & 0.065 \\
\hline 13 & HADGEM & {$[12.4$} & 793.2 & -1.8 & -9.14 & 0.981 & 0.614 & 0.895 & 0.298 \\
\hline 14 & INCM3 & -5.2 & 712.1 & -19.5 & -18.43 & 0.977 & 0.751 & -3.718 & 0.518 \\
\hline 15 & INGSXG & -5.1 & 570.4 & -19.3 & -34.67 & 0.98 & 0.646 & -3.624 & 0.257 \\
\hline 16 & IPCM4 & -10.6 & 512.6 & -24.9 & -41.29 & 0.979 & 0.672 & -6.69 & 0.198 \\
\hline 17 & MIHR & -6.4 & 531.7 & -20.7 & -39.09 & 0.982 & 0.712 & -4.269 & 0.312 \\
\hline 18 & MIMR & -5.9 & 649.6 & -20.1 & -25.59 & 0.987 & 0.709 & -4.044 & 0.421 \\
\hline 19 & MPEH5 & -7.4 & 580.9 & -21.7 & -33.46 & 0.983 & 0.65 & -4.698 & 0.284 \\
\hline 20 & MRCGCM & 12.7 & 873.8 & -1.5 & 0.09 & 0.983 & 0.204 & 0.938 & -0.177 \\
\hline 21 & NCCCSM & 12.8 & 1053.6 & -1.5 & 20.69 & 0.979 & 0.596 & 0.935 & 0.123 \\
\hline 22 & NCPCM & 11.5 & 1105.3 & -2.7 & 26.61 & 0.972 & -0.044 & 0.863 & -1.238 \\
\hline
\end{tabular}

Table 2. Comparison of temperatures and precipitation between simulations of climate models and observations. 


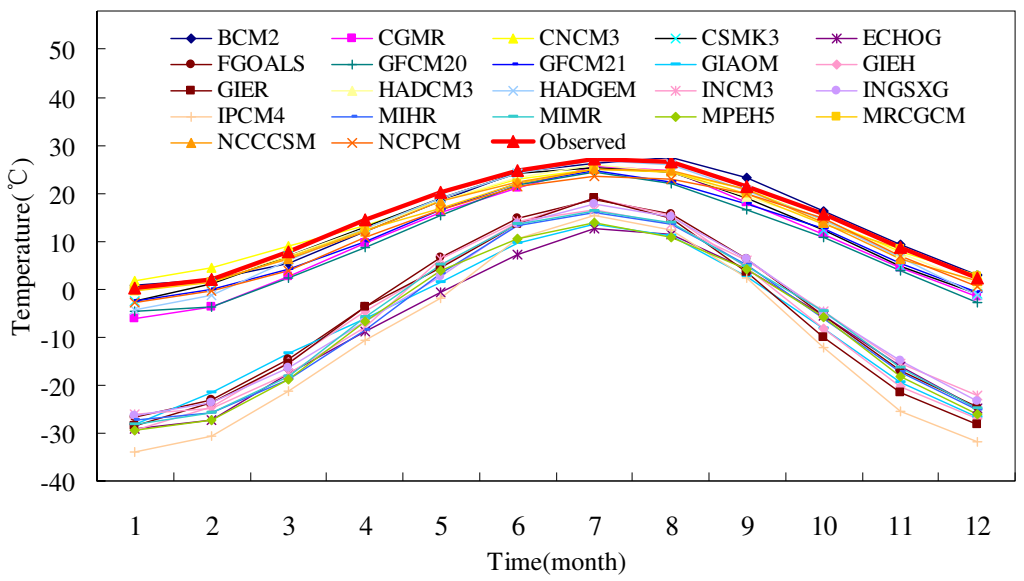

Fig. 2. Comparison of monthly mean temperatures (1961 1990) between simulation and observation in the Huai River Basin.

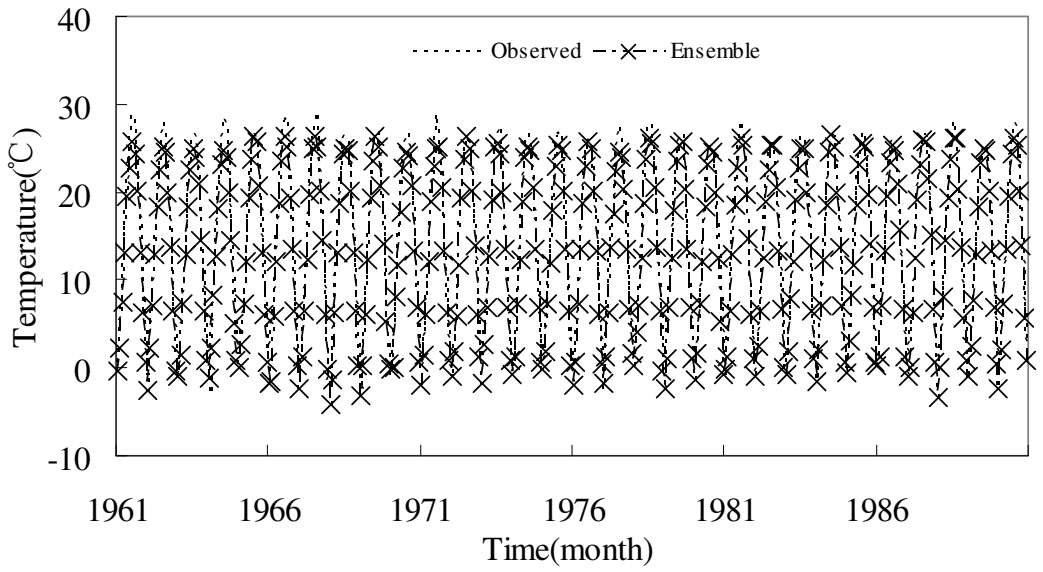

Fig. 3. Comparison of monthly temperature between simulation and observation in reference period (1961 1990) in the Huai River Basin (Ensemble denotes the average temperature of 4 models of CNCM3, CSMK3, HADGEM and NCCCSM).

\subsubsection{Precipitation}

The method for evaluating the models' ability in simulating precipitation is essentially similar to those for temperature. The average annual rainfall of the Huai River Basin in the reference period is $873 \mathrm{~mm}$. It can be seen from Table 2 that most models slightly underestimated precipitation. Abilities of different models in simulating precipitation are remarkably different from each other. Nearly half of the models have unsatisfactory simulation results, among which GIER model has the largest relative error of $65.82 \%$, and MRCGCM model has the smallest relative error of only $0.09 \%$ but with the negative 
determination coefficient value, which means that the fitness is worse than using the average. The correlation coefficient between simulation values and observed values are relatively lower than the correlation coefficient of temperature. Compared to the temperature simulation ability of climate models, precipitation results have lager significant differences (Fig. 4). Simulated results of most models are not ideal. Generally underestimating the precipitation, most models could not properly reproduce the intraannual variation of precipitation. Maximum monthly precipitation was observed in June, but most of the simulated maximum precipitation occurs in July. In terms of the variation in four seasons, the deviation is larger in summer and autumn. In Fig. 5, the average precipitation of CNCM3, CSMK3, HADGEM and NCCCSM, which provide relatively better estimates, are taken for examples to simulate monthly precipitation in the reference period.

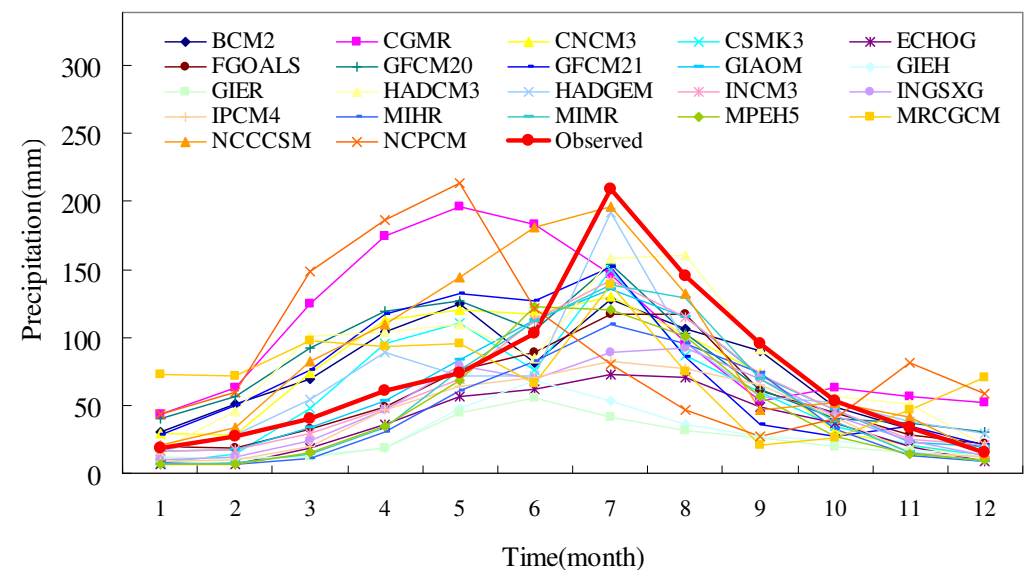

Fig. 4. Comparison of precipitation in the Huai River Basin between simulation and observation in reference period (1961 1990).

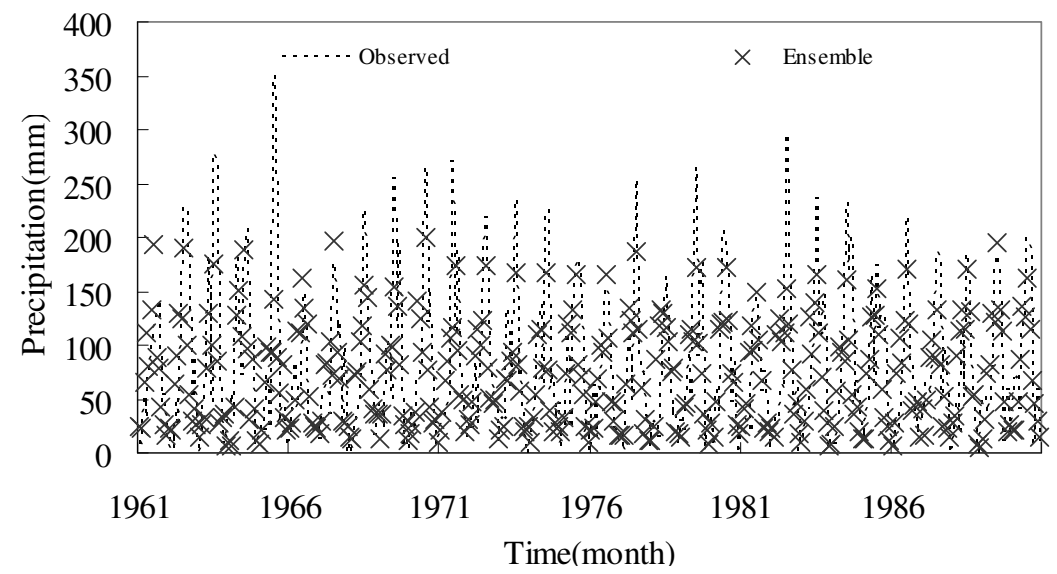

Fig. 5. Comparison of monthly precipitation in the Huai River Basin during the reference period (1961 1990) between simulation and observation (Ensemble denotes the average precipitation of 4 models of CNCM3, CSMK3, HADGEM and NCCCSM). 


\subsection{Future changes in temperature and precipitation}

Table 3 shows the estimated linear trend of average annual precipitation and temperature for the 21st century in the Huai River Basin under different emission scenarios. Analysis shows that the values of the precipitation and temperature tend to increase in the future, except for CSMK3 and GFCM2. For the overall trend, the A2 scenario has the largest increase, followed by the A1B scenario, and the B1 scenario has minimum increase. The increase magnitude differs greatly with the models under the same scenario. The HADCM3 model has the largest increase, up to $369.08 \mathrm{~mm} / 100 \mathrm{a}$ under the A2 scenario. The models of MIMR and ECHOG have larger temperature change tendency of $7.3^{\circ} \mathrm{C} / 100 \mathrm{a}$ and $6.9^{\circ} \mathrm{C} / 100 \mathrm{a}$ respectively under the A2 scenario, and NCPCM has the smallest one of $2.6^{\circ} \mathrm{C} / 100 \mathrm{a}$, while increases predicted with other models are between 3.0 and $6.5^{\circ} \mathrm{C} / 100 \mathrm{a}$. Future warming predicted by $\mathrm{B} 1$ scenario is relatively small with a tendency rate lower than $4.0^{\circ} \mathrm{C} / 100 \mathrm{a}$. Future climate tends to be warm and wet.

\begin{tabular}{ccccccc}
\hline & \multicolumn{3}{c}{ Precipitation $(\mathrm{mm} / 100$ years $)$} & \multicolumn{3}{c}{ Temperature $\left({ }^{\circ} \mathrm{C} / 100\right.$ years $)$} \\
\cline { 2 - 7 } Model & $\mathrm{A} 2$ & $\mathrm{~A} 1 \mathrm{~B}$ & $\mathrm{~B} 1$ & $\mathrm{~A} 2$ & $\mathrm{~A} 1 \mathrm{~B}$ & $\mathrm{~B} 1$ \\
\hline BCM2 & $/$ & 216.9 & 113.9 & 3.1 & 2.8 & 1.4 \\
CGMR & $/$ & 189.5 & $/$ & $/$ & 2.5 & $/$ \\
CNCM3 & 161.3 & 115.2 & $/$ & 4.0 & 3.3 & 1.6 \\
CSMK3 & 63.1 & 55.2 & -10.3 & 3.2 & 2.7 & 1.9 \\
ECHOG & 107.7 & 70.5 & $/$ & 6.9 & 7.2 & $/$ \\
FGOALS & $/$ & 103.5 & 59.9 & $/$ & 3.7 & 2.2 \\
GFCM20 & 195.5 & 144.9 & 125.8 & 4.0 & 4.1 & 2.0 \\
GFCM21 & 185.7 & 53.0 & -29.4 & 3.5 & 3.7 & 2.1 \\
GIAOM & $/$ & 65.3 & 58.8 & $/$ & 2.8 & 1.5 \\
GIEH & $/$ & 53.1 & $/$ & $/$ & 3.2 & $/$ \\
GIER & 18.2 & $/$ & -2.1 & 4.3 & 2.6 & 1.2 \\
HADCM3 & 369.1 & 273.8 & 177.3 & 5.0 & 4.7 & 3.1 \\
HADGEM & $/$ & $/$ & $/$ & $/$ & $/$ & $/$ \\
INCM3 & $/$ & 87.8 & 61.5 & $/$ & 3.5 & 2.3 \\
INGSXG & $/$ & 7.9 & $/$ & $/$ & 4.7 & $/$ \\
IPCM4 & 53.1 & 78.7 & 19.7 & 6.2 & 5.4 & 3.5 \\
MIHR & $/$ & 169.6 & 66.5 & $/$ & 5.9 & 3.6 \\
MIMR & 133.1 & 114.1 & 69.4 & 7.3 & 6.2 & 3.3 \\
MPEH5 & 18.7 & 39.2 & 65.9 & 6.4 & 6.2 & 3.9 \\
MRCGCM & 97.6 & 52.9 & 48.9 & 3.8 & 3.8 & 2.2 \\
NCCCSM & 291.0 & 171.9 & 69.6 & 4.2 & 2.9 & 1.3 \\
NCPCM & 129.3 & 114.1 & $/$ & 2.6 & 2.4 & $/$ \\
\hline
\end{tabular}

Table 3. Linear trend of temperature and precipitation simulated with models in 2000 to 2099 in the Huai River Basin.

\subsection{Selection of climate models}

By comparing the simulated and observed temperature changes (as shown in Fig. 2) of the Huai River Basin during 1961 to 1990, it can be seen that the change trends of these 
models during the year can be divided into two groups. One group is consistent with the measured trend and has the determination coefficient higher than 0 (Table 2); the other group has larger difference from the observed distribution process during the year (greater curvature) and negative determination coefficients. Comparison between the simulated and observed precipitation changes (Fig. 4) also shows that the greater the model's determination coefficient is, the more consistent the distribution process is with the observation. The determination coefficients larger than 0 for both the temperature and the precipitation are therefore, regarded as the first criteria for model selection in this paper. Seven models, BCM2, CNCM3, CSMK3, HADCM3, HADGEM, GFCM20, and NCCCSM meet the first requirements. The BCM2, HADCM3 and GDCM20 models are excluded while considering both the precipitation relative error and degree of fit of the intra-annual variation curve. HADGEM is also excluded because it does not provide monthly temperature and precipitation. Three climate models including CNCM3, CSMK3, and NCCCSM are therefore selected to estimate the hydrological response of future climate change under three IPCC emission scenarios of A1B, A2 and B1 in the Huai River Basin.

\section{Construction of the distributed Xinanjiang model}

\subsection{Theory and data preparation of the Xinanjiang model}

The Xianjiang model is a conceptual watershed model, which was originally developed for simulating streamflow at the daily scale or flood-event scale (Zhao, 1992; Ju et al., 2009). The key concept of the model is that runoff is only generated where the field capacities are reached. The model uses a single parabolic curve to statistically account for the non-uniform distribution of the area of runoff generation. With 14 parameters, the Xianjiang model can simulates the monthly runoff, flow routing and evapotranspiration through four main calculation processes including evapotranspiration, runoff generation, runoff dividing computation and flow routing. The runoff is composed of the surface flow, subsurface flow and groundwater flow.

The structure of Xinanjiang model is shown in Fig. 6 (Zhao, 1992; Ju, et al., 2009). All symbols outside the blocks are parameters. The meaning of all the parameters listed in Table 4. P, EM represent areal mean rainfall and measured pan evaporation, which are the input model. The outputs from the whole basin are the discharge TQ. E is the actual evapotranspiration, including three components EU, EL and ED. T is the total inflow of river network. W, S are the areal mean tension water storage, and the areal mean free water storage, respectively. The areal mean tension water $\mathrm{W}$ has three components. WU, WL, and WD are mean tension water for the upper, lower and deep layers, respectively. The FR is contributing area factor for runoff which is related to W. IM is the factor of percentage of impervious area in the watershed. 1-FR-IM is non-contributing area factor for runoff. The rest of the symbols inside the blocks are all internal variables. RB is the runoff directly from the small portion of impervious area. $\mathrm{R}$ is the runoff produced from the area and divided into three components RS, RI, and RG representing surface runoff, interflow and groundwater runoff respectively. The three components are further transferred into QS, QI, and QG, and collectively form the total inflow to the channel network of the sub-basin. The outflow of the sub-basin is $\mathrm{Q}(\mathrm{Ju}$, et al., 2009). 
The principles of the monthly Xinanjiang model are similar to the daily model. This study implements the distributed monthly Xianjiang model for the Huai River Basin, developed by Hao and Su (2000). Considering the uneven spatial distribution of precipitation, the upstream area of Benbu is divided into 13 computation units through the Thiessen polygon method. Runoff generation and flow routing computations are performed for each unit. The predicted streamflow for the basin is the sum of the runoff at each unit. We calibrated the model using the data between 1961 and 1990 and verified the model for the period of 1991 and 2000. The input data are monthly observations of precipitation and temperature at each gauging station in the area, while the output is monthly streamflow.

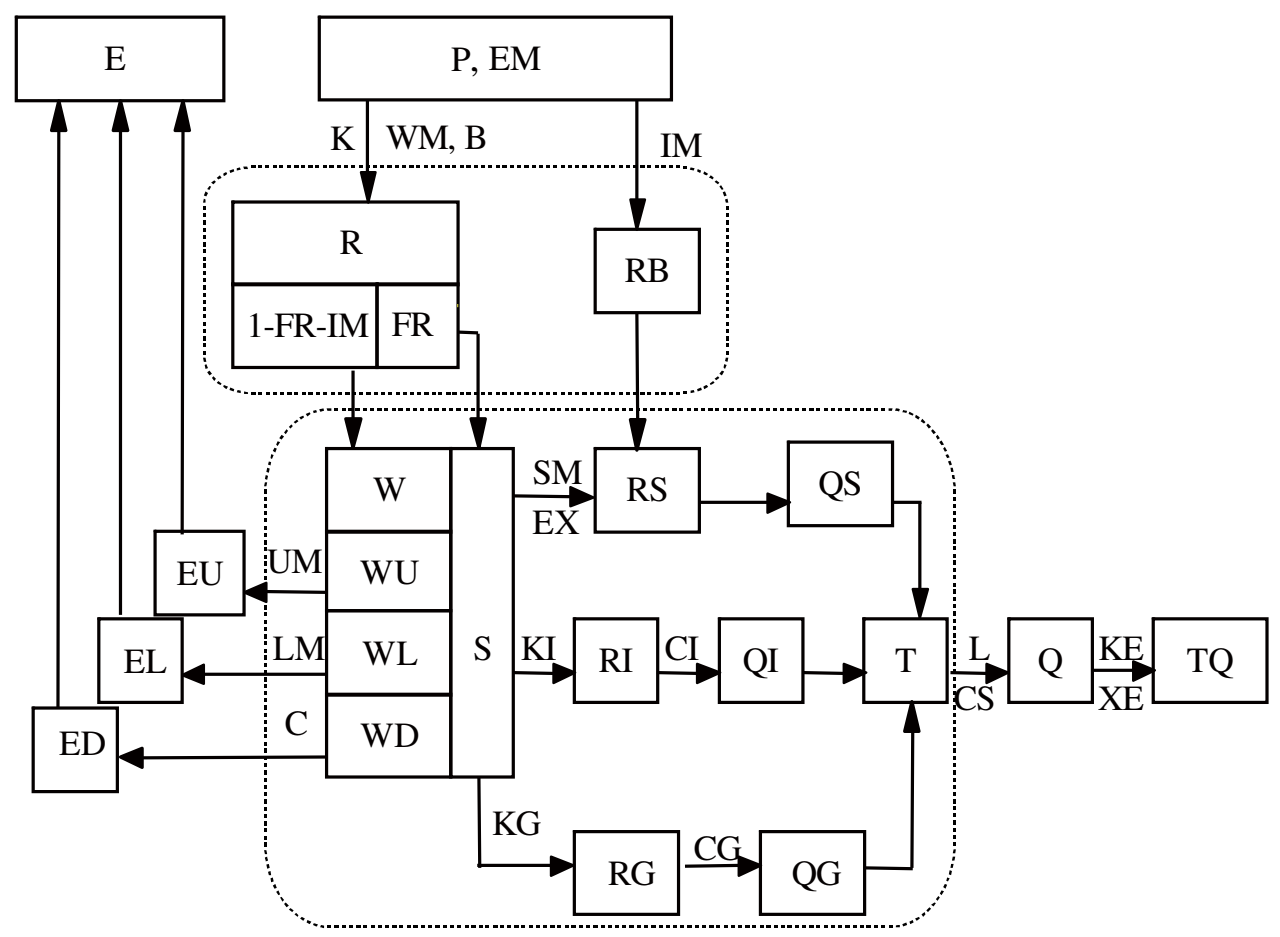

Fig. 6. Structure of the Xinanjiang model (Ju, et al., 2009).

\subsection{Model calibration and validation}

The 14 parameters for the model are calibrated through the trial and error method. The initial values for all the parameters are empirically determined. A set of optimum values of these parameters are determined by a comparison between the predicted and observed discharges (Table 4). 


\begin{tabular}{|c|c|c|c|}
\hline Type & Notation & Parameter Meaning & Value \\
\hline \multirow{4}{*}{$\begin{array}{c}\text { Evapotrans- } \\
\text { piration } \\
\text { parameters }\end{array}$} & K & $\begin{array}{l}\text { Ratio of potential evapotranspiration to the pan } \\
\text { evaporation }\end{array}$ & 0.56 \\
\hline & UM & Tension water capacity of upper layer & 39 \\
\hline & $L M$ & Tension water capacity of lower layer & 83 \\
\hline & C & Evapotranspiration coefficient of deeper layer & 0.12 \\
\hline \multirow{4}{*}{$\begin{array}{c}\text { Runoff } \\
\text { production } \\
\text { parameters }\end{array}$} & $W M$ & Areal mean tension water capacity & 299 \\
\hline & $B$ & Exponential of the distribution of tension water capacity & 0.35 \\
\hline & $I M$ & Ratio of impervious area to the total area of the basin & 0.01 \\
\hline & $S M$ & Free water storage capacity & 9.2 \\
\hline \multirow{3}{*}{$\begin{array}{c}\text { Runoff } \\
\text { separation } \\
\text { parameters }\end{array}$} & $E X$ & Exponential of distribution water capacity & 1.1 \\
\hline & KG & $\begin{array}{l}\text { Out flow coefficient of free water storage to the } \\
\text { ground water flow }\end{array}$ & 0.597 \\
\hline & $K I$ & Out flow coefficient of free water storage to the inter flow & 0.403 \\
\hline Runoff & $C I$ & Recession constant of lower interflow storage & 0.197 \\
\hline concentration & $C G$ & Recession constant of groundwater storage & 0.452 \\
\hline parameters & CS & Recession constant of channel network storage & 0.003 \\
\hline
\end{tabular}

Table 4. Parameters of Xinanjiang model after calibration.
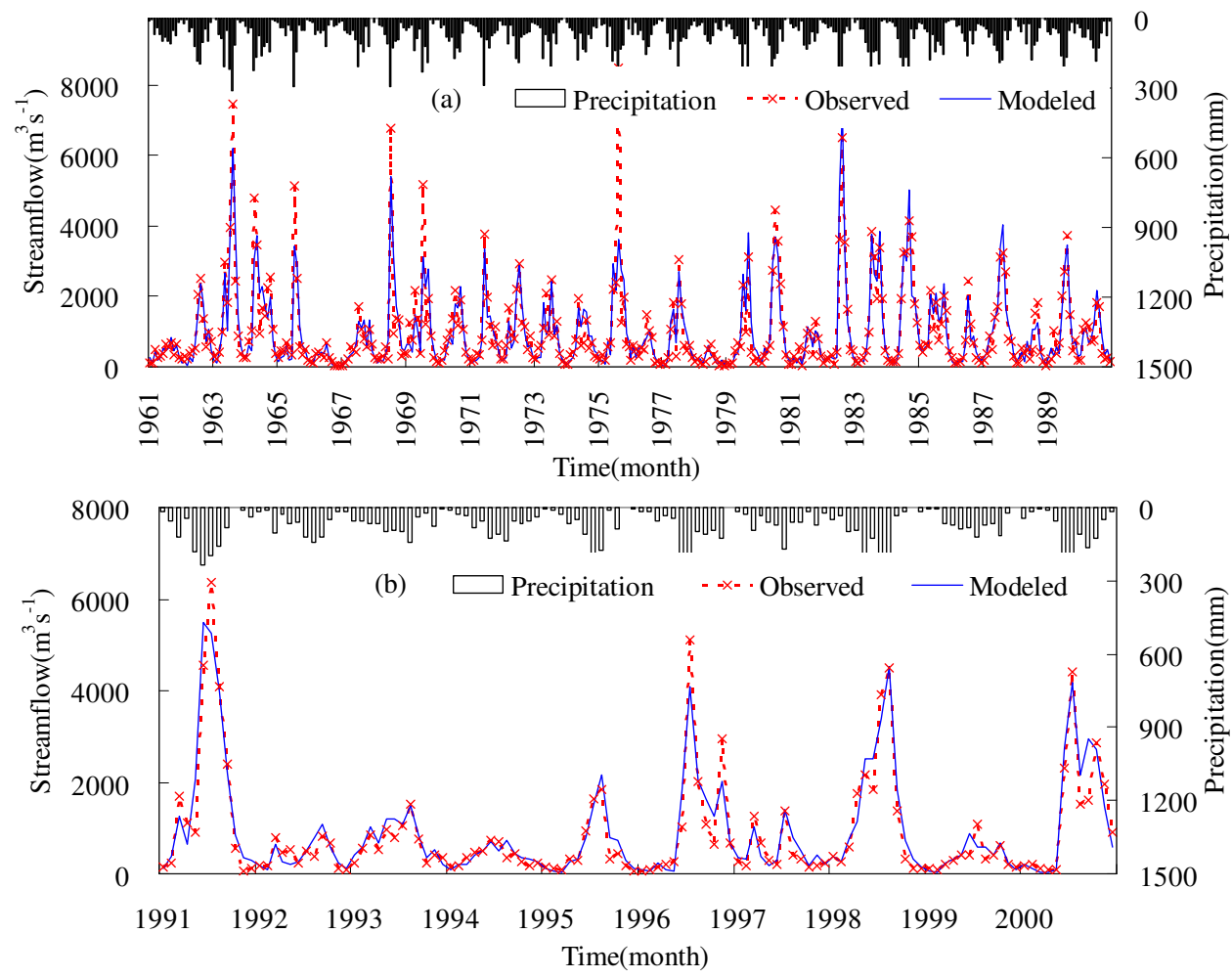

Fig. 7. Simulated and observed monthly streamflows at Bengbu gauge in Huai River Basin; (a) calibration period (b) test period. 
Two error indexes, the mean relative error and the determination coefficient, are selected to evaluate the performance of the models. In calibration and validation periods, the mean relative error MRE are $2.3 \%$ and $7.8 \%$, respectively, and the determination coefficients $\mathrm{E}$ are 0.828 and 0.852 , respectively. A comparison of observed versus simulated monthly streamflows at Bengbu gauge for the calibration period and validation period is shown in Fig. 7. Results show that the constructed distributed monthly Xinanjiang model can reproduce the monthly average runoff process and seasonal changes. Therefore, the model can be used to carry out the assessment study of future impact of climate change on the basin discharge.

\section{Impact of future climate change on water resources}

\subsection{Analysis for yearly runoff trend}

Pearson III frequency curve is selected in this paper to analyze annual runoff frequency of the Bengbu station (1915-2007, removing a small amount of missing data year). Those years with the frequency of less than $25 \%$ on the runoff frequency curve are generally defined as wet year, those between $25 \%$ and $50 \%$ as the normal year, and those more than $75 \%$ as dry year. It can be seen from the normal annual flow frequency curve Fig. 8 that the flow limits at Bengbu station for wet years, normal years and dry years are $1184 \mathrm{~m}^{3} / \mathrm{s}, 829 \mathrm{~m}^{3} / \mathrm{s}$, and $553 \mathrm{~m}^{3} / \mathrm{s}$, respectively. The percentage of the wet, normal and dry yea are $30.9 \%, 41.2 \%$, $27.9 \%$, respectively. Table 5 shows runoff frequency curves for the projected future climates.

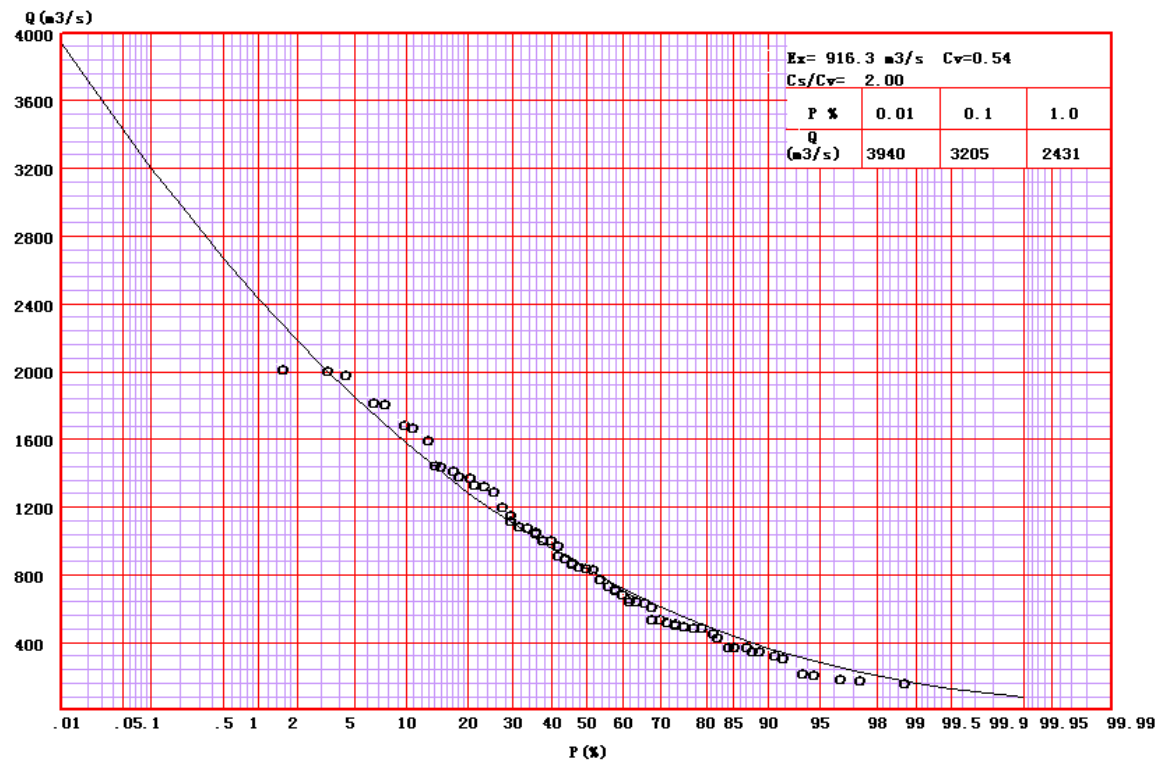

Fig. 8. The empirical frequency curves of yearly streamflows at Bengbu gauge on Huai River Basin during 1915-2007. 


\begin{tabular}{cccccccccc}
\hline Model & \multicolumn{3}{c}{ A2 } & \multicolumn{3}{c}{ A1B } & \multicolumn{3}{c}{ B1 } \\
CNype & CNCM3 & CSMK3 & NCCCSM & CNCM3 & CSMK3 & NCCCSM & CSMK3 & NCCCSM & Total \\
\hline $\begin{array}{c}\text { wet } \\
\text { year(\%) } \\
\text { normal } \\
\text { year(\%) } \\
\text { dry } \\
\text { year(\%) }\end{array}$ & 2.2 & 20.0 & 26.7 & 8.9 & 23.3 & 34.4 & 18.9 & 21.1 & 19.4 \\
\hline
\end{tabular}

Table 5. The statistics for percentage of the wet, normal and dry year under the A2, A1B and B1future scenarios annual runoff with different climatic models during 2010 -2099.

Totally, there are more dry years in the A2 scenario. Normal year dominate in A1B and B1 scenarios, meanwhile wet year and dry year are roughly equal to each other (Fig 9.). In the 8 model projections involved, there are 140 wet years, accounting for $19.4 \%$ of the total, which is slightly lower when compared to the history. There has been a modest decrease in dry years, while normal years increased to $57.8 \%$.

The annual runoff prediction process in the three emission scenarios of A1B, A2 and B1 is shown in Fig. 9. Overall, the future annual runoff are relatively stable, but the simulation results vary from each other. The $\mathrm{CNCM} 3$ model has evidently more dry years under the three scenarios. On the contrary, the NCCCSM model has more wet years. For the CSMK3 model, wet years and dry years are roughly equal (see statistics in Table 5). Generally, in the next 90 years, the annual average flow of the Bengbu hydrological station in the 8 situations is $866 \mathrm{~m}^{3} / \mathrm{s}$, decreasing by approximately $12 \%$ from the historical (1961-1990) annual average flow (987 m³ $/ \mathrm{s})$. Historical annual average rainfall is $873 \mathrm{~mm}$, while the future average rainfall will be $884 \mathrm{~mm}$, which is a slight increase of $1.1 \%$. The historical temperature is $14.2^{\circ} \mathrm{C}$, while the future average temperature increases by $2.9^{\circ} \mathrm{C}$ (Fig. 10). A smaller precipitation increase and a larger temperature increase will occur in the future in the Huai River Basin. The two changes have contradictory effects on the runoff. The evaporation caused by temperature rise, however, greatly surpasses the runoff increase caused by precipitation increase, leading to the decrease trend of the runoff in the future. This will be a large challenge for both the sustainable development of water resources in the Huai River Basin and the allocation and the management of water resources in the East Line of the Water Transfer Project.

As shown in the frequency distribution of annual average flow (Fig. 11) in 2020s, 2050s, 2080s and the reference period(1961-1990), it can be seen that the mean of most scenarios shift to the left in 2020s. The highest point of the annual average flow probability density is larger than that of the history in most climate projections, Similar to 2020s, most climate projections shift to the left and become thinner in 2050s and 2080s, which further indicated that the frequency of low flows in future years will increase, possibly with the trend of average annual flow reduced in the future. Most scenarios indicate that the frequency of low flows in future years will increase, possibly with a trend of reduced values. Right-shift of the probability density curve for a few climate projections indicates that the frequency of high flows in future years would increase in those cases. 

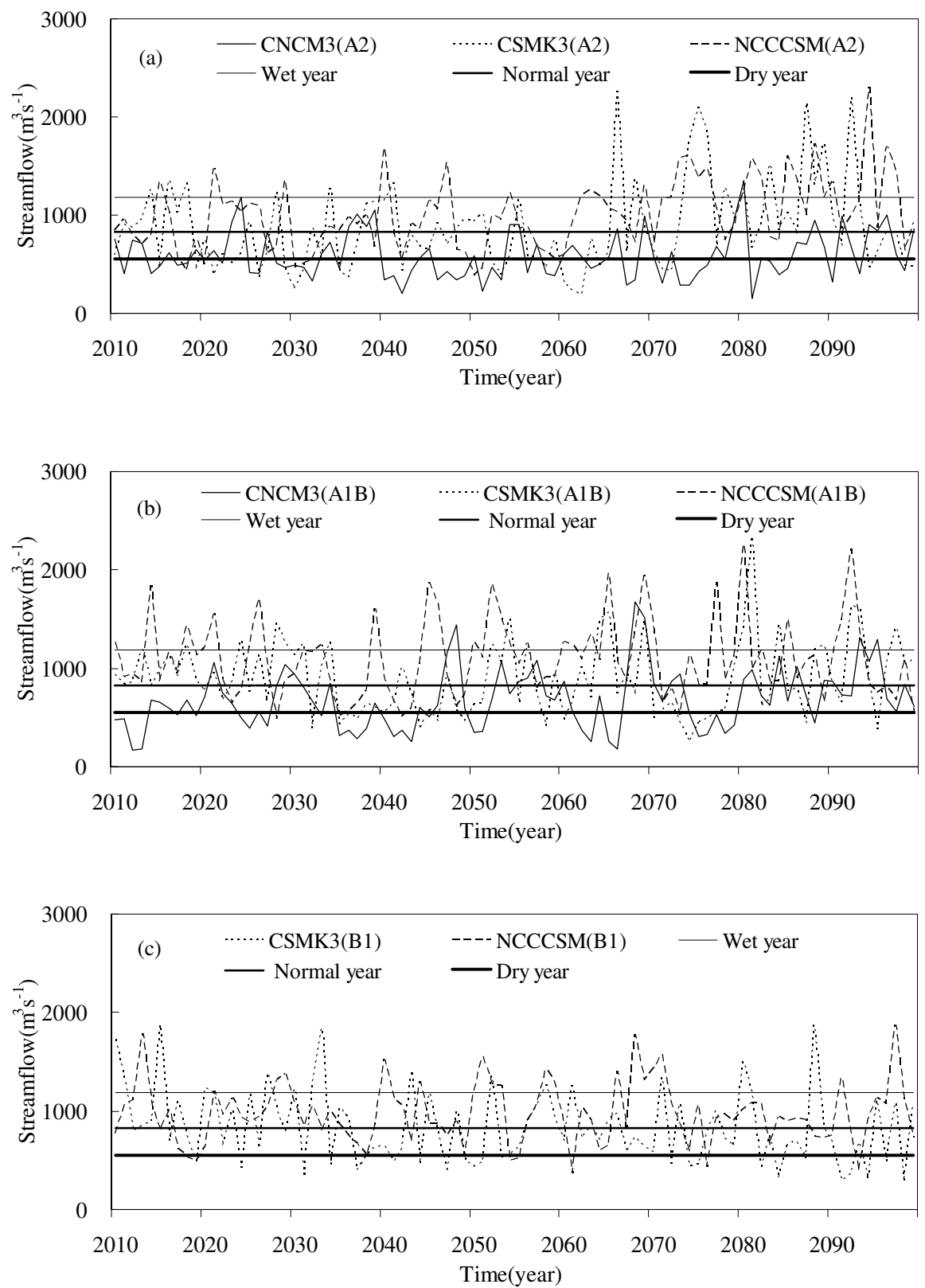

Fig. 9. Simulated annual streamflows under the different future scenarios at Bengbu gauging station in the Huai River Basin during 2010 -2099, (a)A2 scenarios; (b)A1B scenarios; (c) B1 scenarios. 


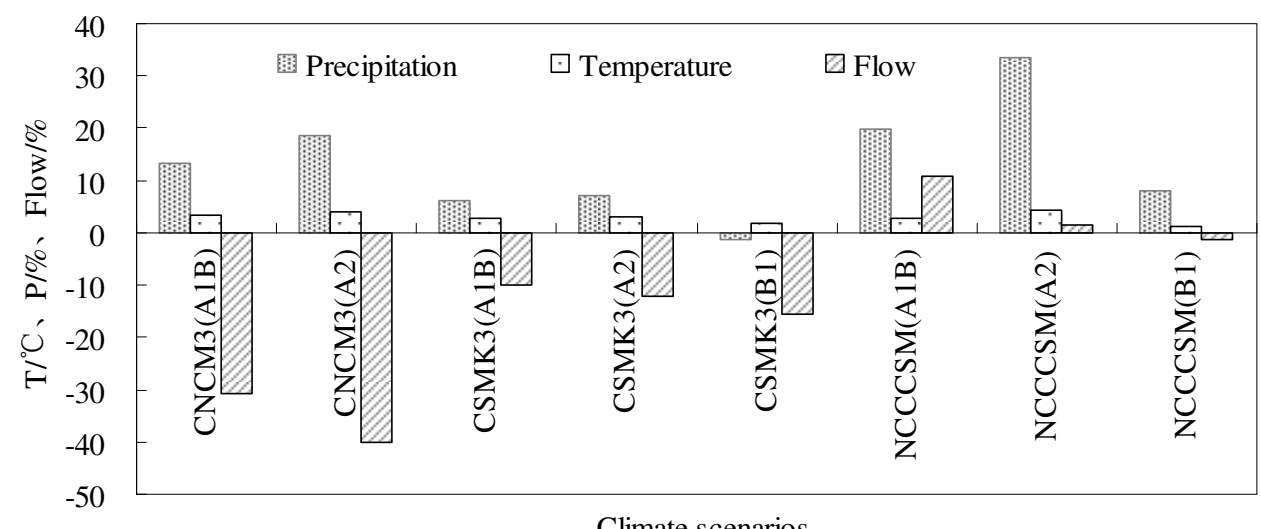

Fig. 10. Projections of annual runoff to change of precipitation and temperature under different climate scenarios during 2010 -2099 in the Huai River Basin.
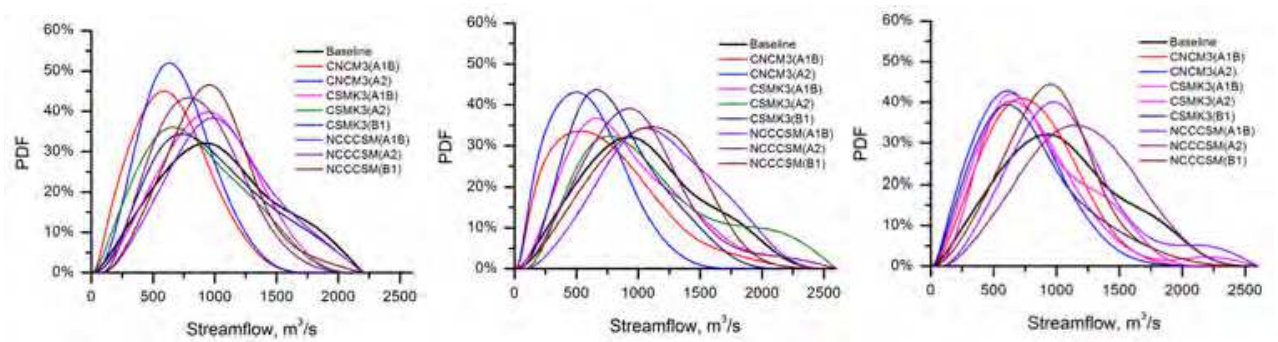

Fig. 11. Probability density function of annual mean discharge and the $90 \%$ confidence interval for 2020s(2010-2039), 2050s(2040-2069), 2080s (2070-2099) and the baseline (1961-1990).

\subsection{Monthly runoff analysis}

Fig. 12 is the monthly hydrograph of each climate scenario and the multi-scenario ensemble mean in different periods. The estimated maximum flow of most models appears in July, basically consistent with the historical measurement. But the estimated values are all lower than the measured ones, except that the NCCCSM model's flows in July under the A1B scenario in 2050s and under the A2 scenario in 2080 are both slightly higher than the measured flow. The average monthly flow of the NCCCSM model in B1 scenario is the most consistent with historical trends in the next three decades. For the NCCCSM model in 2050s and 2080s under scenario A1B, flows of July and August are overestimated. Among the eight scenarios, estimated flows of the CNCM3 model under the A1B and A2 scenarios are the lowest. The ensemble mean flows of July and August in the three decades tend to decrease, whereas no significant change is observed in other months. By analyzing the change ranges of all scenarios, we can see that the estimated results of June, July, August and September have much larger model-to-model differences compared with the reference period. This uncertainty increases with time. The uncertainty range of other months is relatively smaller. 

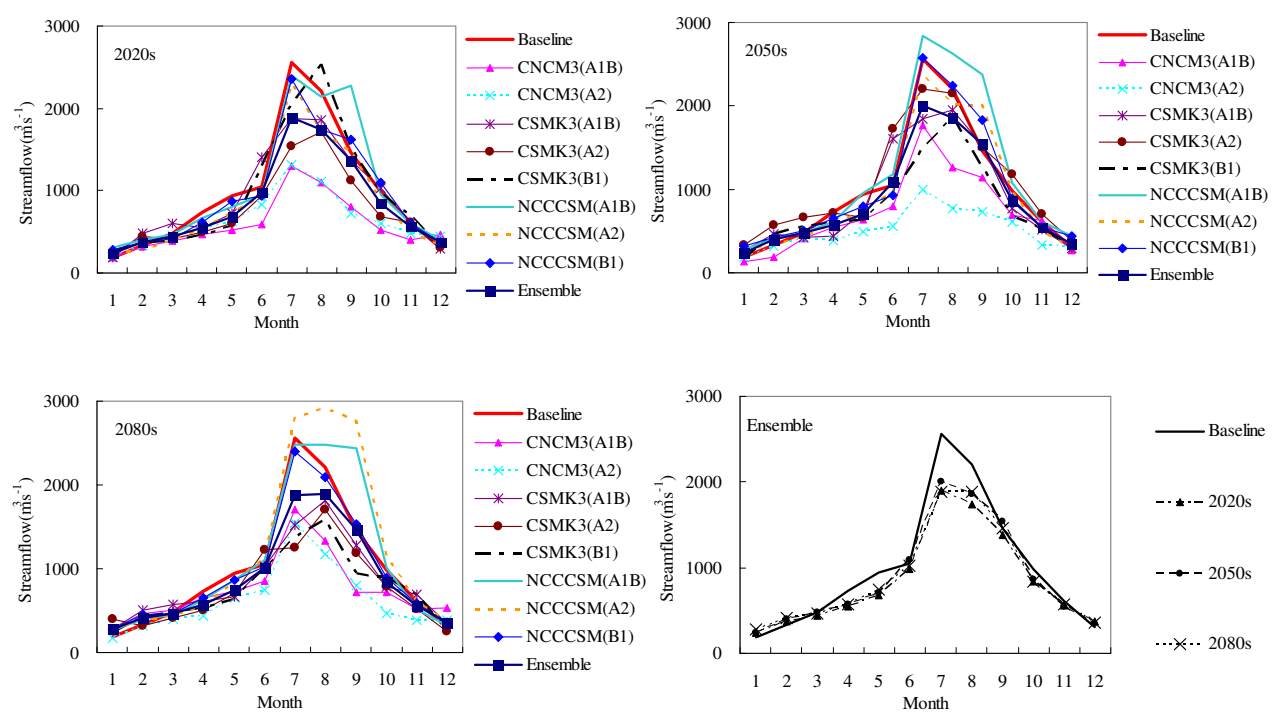

Fig. 12. Comparison of monthly flow curve for many years with different climatic models under the A2, AB and B1future scenarios at Bengbu gauge (baseline denote 1961-1990, Ensemble represent the average flow of the eight climate projections).

\subsection{The runoff change analysis in flood season}

The flood season of the Huai River Basin is from May to September. Other months are grouped into non-flood period. Fig. 13 shows the relative percentage change of the average flood season runoff in 2020s, 2050s and 2080s relative to that of the reference period (19611990). Most simulation results of the three periods were lower than the reference period. Predictions of different models vary widely from each other. Simulated results of the CNCM3 model in the three periods are all less than the reference period. Under the conditions of Special Report on Emissions Scenarios A2, the runoff has a substantial reduction of about $50 \%$. Simulated results of CSMK3 are higher than CNCM3 but lower than NCCCSM. NCCCSM results for the A1B scenario in the 2020s, all three scenarios in the 2050s, the A1B and A2 scenario in the 2080s, produce higher streamflows than in the baseline period. Most of the simulation results in 2020s are lower than in the reference period, among which the NCCCSM model, under A1B scenario, has the highest simulated results, which is $108 \%$ of the reference period. Simulated results of both CNCM3 and CSMK3 in 2050s are lower than the reference period; part of the NCCCSM model's scenarios is above the reference period but the ratio is not significant. Simulated results of 2080s are significantly higher than those of 2020s, among which the NCCCSM model, under the A2 scenario, has the highest simulated result of $133 \%$. The total range of streamflow rates in the flood season between the various scenarios and models, expressed as a percent of their corresponding rates in the baseline period, was $56 \%$ in the 2020 s ( $52 \%$ to $108 \%$ ), but about $80 \%$ in the 2050 s and 2080 s. This increase from $56 \%$ to $80 \%$ represents a growth in the uncertainty of the predictions into the more distant future. 


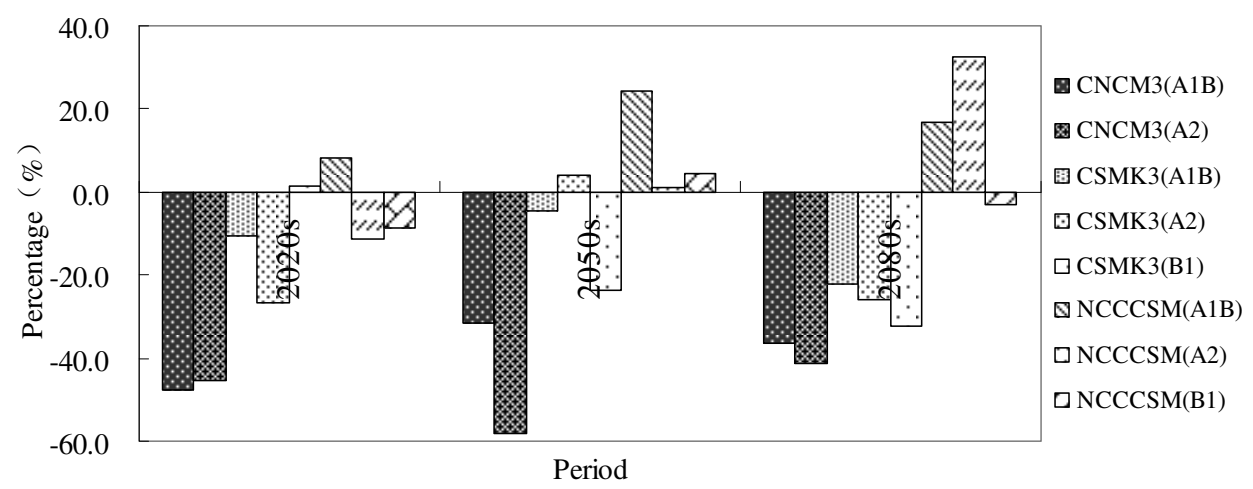

Fig. 13. The flood season Seasonal and annual runoff during 2020s, 2050s and 2080s in the Huai River Basin, as a percentage of the runoff in the baseline(1961-1990) period.

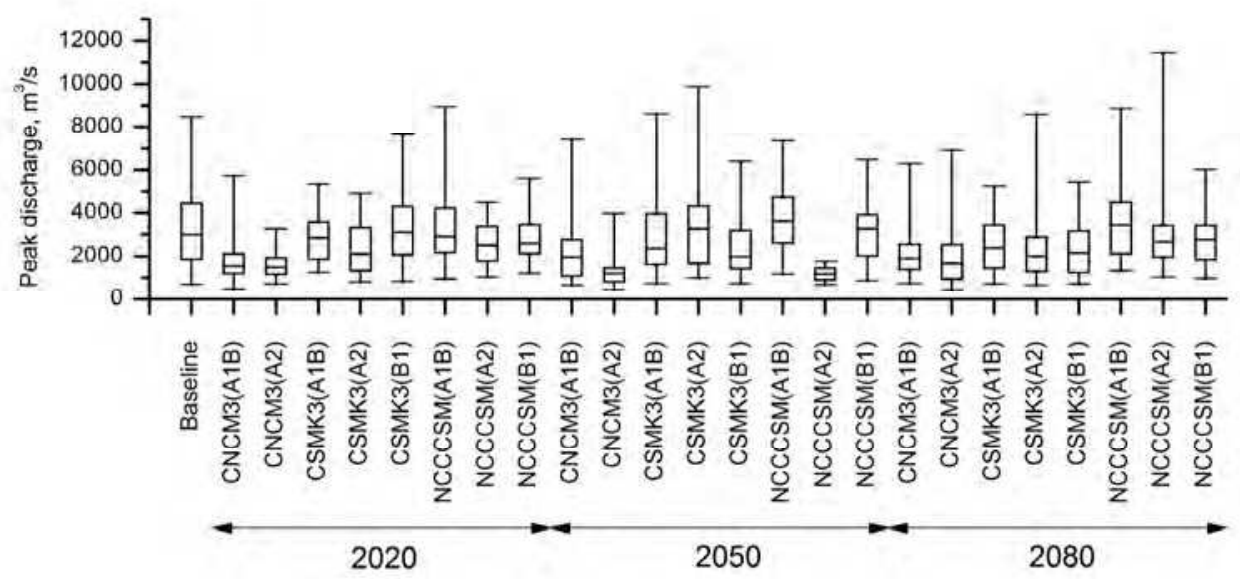

Fig. 14. Box plots of peak discharge for 2020s, 2050s, 2080s and the baseline(1961-1990).

\subsection{Analysis of peak flow changes}

Climate change will exacerbate the global and regional hydrological cycle process, affecting the spatial and temporal distribution of such water cycle factors as precipitation, evaporation, runoff and soil moisture, causing re-allocation of water resource in time and space, thus enhancing the possibility of various extreme hydrological events. Here, we mainly analyze the change trend of peak flow rate (annual maximum monthly flows, reference period refers to the maximum monthly flow form 1961 to 1990). Fig. 14 is the box plot diagram of the peak flow in the three estimate periods and the reference period. The median value of peak flows in the reference period is $3060 \mathrm{~m}^{3} / \mathrm{s}$, while median values 
of most scenarios in the future are lower than the reference period, indicating the reduction trend of peak flow in the flowing years. Only five median values of estimated peak flows - Model CSMK3 under the B1 and A2 scenarios in 2020s, Model NCCCSM under the A1B and B1 scenarios in 2050s, and Model NCCCSM under the A1B scenario of in 2080s - are higher than the reference period. And the NCCCSM model produces highest median peak flow under the A1B scenario in 2050s. Compared with the minimum value in reference period, minimum values for the majority of future scenarios are lower, indicating the less frequent occurrence of lower peak flow in the future. Compared with maximum value of the reference period, a small part of simulations such as that under the A1B scenario predicted with NCCCSM in 2020s, the A1B and A2 scenarios with CSMK3 in 2050s, the A2 scenario with CSMK3 in 2080s, as well as the A1B and A2 scenarios with NCCCSM, have higher maximum values, indicating the less frequent occurrence of higher peak flow in the future. The uncertainty scope of the future three periods also gradually increases with time.

\section{Conclusions and discussions}

Based on the predicted results of 8 global climate model scenarios in the Fourth Assessment by IPCC, this study used the distributed Xin'anjiang hydrological model to simulate runoff of the Bengbu hydrological station in the Huai River Basin in the next 90 years. The monthly runoff, flood season runoff, the annual runoff and the change trends of the peak flow are analyzed comparatively and the following conclusions are made:

1. Twenty-two global circulation models released by the Fourth Assessment of IPCC were tested in the Huai River Basin. Compared with the reference period, three evaluation indexes including the mean relative error, correlation coefficient and determination coefficient are used to evaluate the performance of GCMs. Three climate models, CNCM3, CSMK3 and NCCCSM, having better simulation performances in the Huai River Basin, are selected to predict and estimate change trends of the future precipitation and temperature under three emission scenarios, A1B, A2 and B1.

2. Compared with the average annual flow of the reference period, the future average annual flow decreases and dry season runoff is lower than for the reference period. The frequency of years with low annual flow will increase in the future. The A2 scenario has the largest number of predicted dry years, and more dry years than wet years. Normal years dominate in the $\mathrm{A} 1 \mathrm{~B}$ and $\mathrm{B} 1$ scenarios, for which the number of wet years and dry years are roughly equal. The $\mathrm{CNCM} 3$ model predicts more total dry years under all three scenarios, and much more dry years than wet years. By contrast, the NCCCSM model has more wet years than dry years. For the CSMK3 model, wet years are roughly equal to dry years.

3. Compared with the monthly flow of the reference period, the maximum flow of most models is in July, which is consistent with the historical measurement, but the hydrological model estimated values are lower than the measured values. The NCCCSM model, B1 scenario, projects streamflow rates for the future three decades that are the closest from among all of the experiments to its reference rates in the baseline period. The ensemble mean flows of July and August in the future tend to 
decrease, while other months will not change significantly. Predicted results in summer months of June, July, August and September have the largest differences from the reference period; the range of uncertainty increases with the length of prediction time.

4. Compared with monthly flow of the reference period, the future annual average runoff in flood season decreases. CNCM3 has the largest reduction and NCCCSM decreases the minimum. A2 scenario of NCCCSM model has the largest increase in flood season runoff, which is $133 \%$. The estimated uncertainty range in 2050s and 2080s is larger than that in 2020s.

5. The future peak flow tends to decrease, the estimated values of only a small proportion of scenarios are higher than that of the reference period, indicating that the frequency of flood peak flow tends to decrease, but extreme flows higher than the historical maximum will also appear in 2080s. The uncertainty range of the three periods in the future also increases gradually with time.

Hydrological responses estimated from climate change scenarios can provide reference information for regional water resources management, but hydrological forecasting is a more developed approach. The scenario estimates are based on assumptions that have greater uncertainty than hydrological forecasts. Here we applied the ensemble method which constructs multi-GCMs and multi-emission scenarios to coupled meteorological hydrological forecasts. Results show that the ensemble method can improve the accuracy of simulations to some extent. Therefore, further study is needed in model selection, the corresponding ensemble mean method, selection of uncertain quantitative assessment indexes and estimate methods when we assess the possible climate change impact.

\section{Acknowledgments}

This work was financially Supported by the National Natural Science Foundation of China (40830639, 50879016, 41101015), the National Basic Research Program of China (2010CB951101), the "Strategic Priority Research Program - Climate Change: Carbon Budget and Relevant Issues" of the Chinese Academy of Sciences (XDA05110102), China Postdoctoral Science Foundation funded project (20110491346) and the Special Fund of State Key Laboratory of Hydrology-Water Resources and Hydraulic Engineering (106950985512).

\section{References}

Berkoff, J., 2003. China: The South-North Water Transfer Project-is it justified? Water Policy. $5: 1-28$.

Beyene, T., Lettenmaier, D. P., Kabat, P, 2010. Hydrologic impacts of climate change on the Nile River Basin: implications of the 2007 IPCC scenarios. Climatic Change , 100, 433-461.

Beyene, T., Lettenmaier, D. P., Kabat, P., 2010. Hydrologic impacts of climate change on the Nile River Basin: implications of the 2007 IPCC scenarios. Climatic Change, 100, 433-461. 
Christensen, N. S., Lettenmaier, D.P., 2007. A multimodel ensemble approach to assessment of climate change impacts on the hydrology and water resources of the Colorado River Basin, Hydrology and Earth System Sciences, 11(4):14171434.

Edwin, P. M., 2007.Uncertainty in hydrologic impacts of climate change in the Sierra Nevada, California, under two emissions scenarios. Climatic Change. 82(3-4): 309325.

Ellis, A. W., Hawkins, T. W., Balling, R. C., et al., 2008. Estimating future runoff levels for a semi-arid fluvial system of central Arizona, USA, Climate Resear , 35: 227239.

Hao, Z., Ju, Q., Yu Z., et al., 2010. Evaluation of the simulation performance and scenario projection of IPCC AR4 global climate models on Yangtze River Basin. Quaternary Sciences, 2010, 30(1):127-137. (in Chinese)

Hao, Z.C., Su, F.G., 2000. Modification of the Xinanjiang Grid-based Monthly Hydrological Model. Advances in Water Science 11(supplement), 80-86, (in Chinese)

Hao, Z., Wang, J., Li, L., et al., 2006. Impact of $\mathrm{Cl}$ imate Change on Runoff in Source Region of Yellow River. Journal of Glaciology and Geocryology. 28(1): 1-7. (in Chinese)

IPCC, 2007. Climate Change 2007: Impacts, Adaptation, and Vulnerability. Contribution of Working Group II to the Forth Assessment Report of the Intergovernmental Panel on Climate Change. Cambridge: Cambridge University Press.

Ju, Q., 2009. Research of Climate Change and Response of Water Recycling in Yangtze River Basin. Hohai University, 2009. 25 26. (in Chinese)

Ju, Q., Yu, Z., Hao, Z., et al., 2009. Division-based Rainfall-Runoff Simulations with BP Neural Networks and Xinanjiang models. Neurocomputing, 72, 2873-2883.

Nash, J.E., Sutcliffe, J.V., 1970. River flow forecasting through conceptual models, I. A discussion of principles, Journal of Hydrology, 10, 282-290.

Nash, L., Gleick, P. H, 1991. Sensitivity of Streamflow in the. Colorado Basin to climate change. Journal of Hydrology. 125, 221-241.

Nemec, J., Schaake, J., 1982. Sensitivity of water resources systems to climate variation. Science. 1982, 27(3): 327-343.

Nijssen, B., O'donnell, G. M., Hamlet, A. F., et al., 2001. Hydrologic sensitivityof global rivers to climate change. Climatic Change. 50, 143-175.

Ozkul, S., 2009. Assessment of climate change effects in Aegean river Basins: the case of Gediz and Buyuk Menderes Basins. Climatic Change, 97(1-2):253-283.

Schwarz, H. E., 1977. Climate change and water supply: how sensitive is the Northeast? Washington D C: National Academy of Science.

Young, C. A., Escobar-Arias, M. I., Fernandes, M., et al., 2009. Modeling the hydrology of climate change in California's Sierra Nevada for subwatershed scale adaptation. Journal of the American Water Resources Association. 45(6): 1409-1423.

Zhao, R.J., 1992. The Xinanjiang model applied in China. Journal of Hydrology 135, 371381. 
Zhou T, Yu R. 20th century surface air temperature over China and the globe simulated by coupled climate models. Journal of Climate. 2006, 19(22): 5843-5858. 


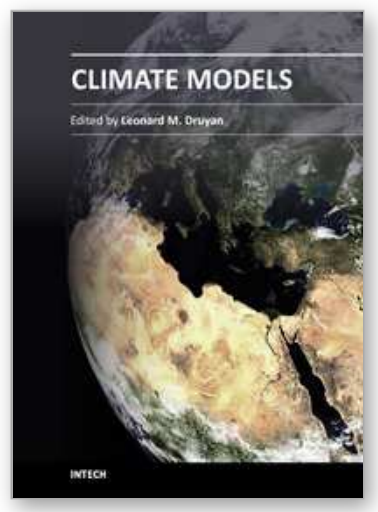

\author{
Climate Models \\ Edited by Dr. Leonard Druyan
}

ISBN 978-953-51-0135-2

Hard cover, 336 pages

Publisher InTech

Published online 02, March, 2012

Published in print edition March, 2012

Climate Models offers a sampling of cutting edge research contributed by an international roster of scientists. The studies strive to improve our understanding of the physical environment for life on this planet. Each of the 14 essays presents a description of recent advances in methodologies for computer-based simulation of environmental variability. Subjects range from planetary-scale phenomena to regional ecology, from impacts of air pollution to the factors influencing floods and heat waves. The discerning reader will be rewarded with new insights concerning modern techniques for the investigation of the natural world.

\title{
How to reference
}

In order to correctly reference this scholarly work, feel free to copy and paste the following:

Ju Qin, Hao Zhen-chun, Ou Geng-xin, Wang Lu and Zhu Chang-jun (2012). Impact of Global Climate Change on Regional Water Resources: A Case Study in the Huai River Basin, Climate Models, Dr. Leonard Druyan (Ed.), ISBN: 978-953-51-0135-2, InTech, Available from: http://www.intechopen.com/books/climate-models/astudy-of-the-impact-of-global-climate-change-on-regional-water-resources

\section{INTECH}

open science | open minds

\section{InTech Europe}

University Campus STeP Ri

Slavka Krautzeka 83/A

51000 Rijeka, Croatia

Phone: +385 (51) 770447

Fax: +385 (51) 686166

www.intechopen.com

\section{InTech China}

Unit 405, Office Block, Hotel Equatorial Shanghai

No.65, Yan An Road (West), Shanghai, 200040, China

中国上海市延安西路65号上海国际贵都大饭店办公楼 405 单元

Phone: +86-21-62489820

Fax: +86-21-62489821 
(C) 2012 The Author(s). Licensee IntechOpen. This is an open access article distributed under the terms of the Creative Commons Attribution 3.0 License, which permits unrestricted use, distribution, and reproduction in any medium, provided the original work is properly cited. 